\title{
NEW SPECIES OF TANYTARSUS VAN DER WULP (DIPTERA: CHIRONOMIDAE:TANYTARSINI) FROM BRAZIL
}

\author{
SUSANA TRIVINHO-STRIXINO ${ }^{1}$, SOFIA WIEDENBRUG ${ }^{2, *}$, \\ and FABIO LAURINDO DA SILVA 3
}

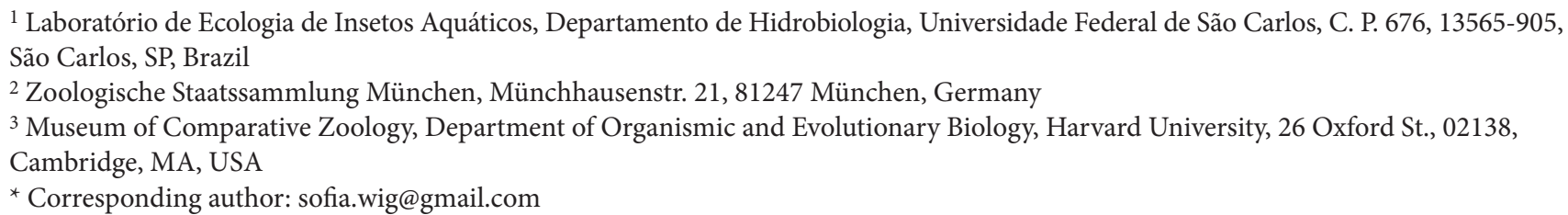

\section{ABSTRACT}

Five new species of Tanytarsus van der Wulp (Diptera: Chironomidae: Tanytarsini) from Brazil are described and illustrated. T. longitubuli sp. n. and T. pseudocurvicristatus sp. n., are described as larva, pupa and male; T. hirsutus sp. n., as male and pupa, and T. corumba sp. n. and T. jatai sp. n. as males. Except for one species from Pantanal (western central Brazil), most species were collected in southeast Brazil, from lowland streams and lakes. New occurrences of known species of Tanytarsus in Brazil, Mato Grosso do Sul and Mato Grosso states, are also given.

Keywords: Brazil, taxonomy, Chironomidae, Tanytarsus, new species

\section{Introduction}

The genus Tanytarsus is one of the most species rich genera of Chironomidae in the Neotropical region, and the immature stages are present in several different aquatic ecosystems. The identification of adults of Tanytarsus is problematical due to the large interspecific variation in the genitalic morphology (Ekrem and Reiss 1999). Despite this drawback, recent years have seen increased interest concerning the taxonomy of the group in the Neotropical region. A detailed revision of the Neotropical Tanytarsus was done by Manzolillo-Sanseverino (2006) and several pupal morphotypes from the region were figured by Wiedenbrug and Ospina-Torres (2005). Additionally, several authors have published new species (Sanseverino and Fittkau 2006; Trivinho-Strixino and Sonoda 2006; Cranston 2007; Trivinho-Strixino and Strixino 2007; Vinogradova et al. 2009; Sanseverino et al. 2010; Sanseverino and Trivinho-Strixino 2010; Gilka and Zakrzewska 2013). The examination of five species of Tanytarsini, not readily identifiable, suggests that these species do not match to any of the currently recognised species of the genus. Therefore, in the present study five new species of Tanytarsus are described and illustrated. The described material was collected in western central and southeast Brazil.

\section{Material and Methods}

Adult material was collected with Malaise traps, while larvae and pupae were collected using a handnet and preserved in $70 \%$ ethanol before being slide mounted in Euparal or Hoyer's solution. Some larvae and pupae were also isolated in small vials covered with nylon screen and reared in laboratory to obtain adult life stages. Morphological terminology and abbreviations follow Sæther (1980). Measurements are given as ranges, with the number of observed specimens in parenthesis if different from the number (n) stated at the beginning of the description. Holotypes and paratypes are deposited in the Museum of Zoology of the University of São Paulo and in the Reference Collection of the Laboratório de Ecologia de Insetos Aquáticos (LEIA), Universidade Federal de São Carlos (UFSCar), São Carlos, Brazil.

\section{Taxonomy}

\section{Tanytarsus corumba sp. $\mathbf{n}$.}

Type material: Holotype male, Brazil, Mato Grosso do Sul, Corumbá, BEP, mata ciliar, Rio Miranda, $19^{\circ} 34^{\prime} 30.06^{\prime \prime} \mathrm{S}, \quad 57^{\circ} 00^{\prime} 52.4^{\prime \prime} \mathrm{W}$, Malaise 3, 02.xi.-02. xii.2011, C. J. E. Lamas and S. S. Nihei (SISBIOTA-Project). 6 Paratypes: 6 males same data as holotype.

Etymology: Named after the type locality, Corumbá in Mato Grosso do Sul State. The name is treated as a noun in apposition.

Diagnostic characters: Anal tergite bands v-type, anal point with parallel sided anal crests, with 3 spines aligned in between; superior volsella quadrate with a median-posterior triangular extension; median margin straight; digitus short, somewhat thumb-like, not extending beyond median margin of superior volsella; median volsella short. 


\section{Description}

Adult male $(n=2)$

Dimensions: Small, length about $2.70 \mathrm{~mm}$. Wing length $0.75 \mathrm{~mm}$.

Coloration: Head yellow-brown, flagellum and maxillary palp pale brown. Thorax yellow-brown. Abdomen yellow. Legs yellow.

Head: AR 0.40-0.85. Antennal flagellomere lengths (in $\mu \mathrm{m}$ ): 1st-12th 260-385 $\mu \mathrm{m}$ long, 13th 150-220 $\mu \mathrm{m}$ long, total length 480-535 $\mu \mathrm{m}$ long. Eyes with dorsomedian extension; frontal tubercles absent; temporal 8 (1); clypeus with 9-10 setae. Palpomeres 1-5 lengths: 20-23, 18-23, 48 (1), 50 (1), 88 (1) $\mu \mathrm{m}$, total length 223 (1) $\mu \mathrm{m}$.

Thorax: Length $0.45 \mathrm{~mm}$. Scutal tubercle absent; acrostichals 7, biserial, beginning near antepronotum, dorsocentrals 4, prealar 1, scutellars 2. Halteres with 4 (1) setae.

Wing $(\mathrm{n}=1)$ : Width $0.21 \mathrm{~mm}$; L/WR 3.57; VR 1.39. Brachiolum with 1 seta, Sc bare, $\mathrm{R}$ with 12 setae, $\mathrm{R}_{1}$ with 9 setae, $R_{4+5}$ with 19 setae, $M$ without setae, $M_{1+2}$ with 24 setae, $\mathrm{M}_{3+4}$ with 11 setae, $\mathrm{Cu}$ with 2 setae, $\mathrm{Cu}_{1}$ with 8 setae, postcubitus with 8 setae and An with 7 setae. Cell m with 2 setae on false vein, $r_{4+5}$ with 70 setae, $m_{1+2}$ with 60 setae, $\mathrm{m}_{3+4}$ with 15 setae, an $+\mathrm{cu}$ without setae.

Legs: Fore leg bearing single tibial pectinate spur, 15 (1) $\mu \mathrm{m}$ long. Mid leg bearing two tibial pectinate spurs, 18; $28 \mu \mathrm{m}$ long and two separated combs. Hind leg bearing two tibial pectinate spurs, $18 ; 28-30$ (2) $\mu \mathrm{m}$ long and two separated combs. Lengths and proportions as in Table 1.

Abdomen: Length 2.20 (1) $\mathrm{mm}$.

Hypopygium (Figs. 1a-e): Tergite IX with 4-8 apical setae and 3 medial setae. Orolateral spine of laterosternite IX absent. Anal tergal bands V-type. Anal point 35-38 $\mu \mathrm{m}$ long, rounded at tip, with pair of well-developed anal crests $18-23 \mu \mathrm{m}$ long, extending posterior to tergite IX; spines placed regularly between anal crests (Fig. 1b). Superior volsella quadrate with a median-posterior triangular extension; median margin straight; 6 setae on dorsal surface, median margin with 3 (Figs. 1c-d). Digitus short, somewhat thumb-like, not extending beyond median margin of superior volsella. Median volsella $8 \mu \mathrm{m}$ long with $10 \mu \mathrm{m}$ long simple setae and 13-15 $\mu \mathrm{m}$ long foliate seta, not reaching apex of inferior volsella (Fig. 1e). Inferior volsella 55-58 $\mu \mathrm{m}$ long, thick. Gonocoxite length 100-108 $\mu \mathrm{m}$ long; gonostylus 60-70 $\mu \mathrm{m}$ long, elongate and slender; hypopygium ratio (HR) 1.53-1.67.

Table 1 Lengths (in $\mu \mathrm{m}$ ) and proportions of leg segments in Tanytarsus corumba sp. $n$., male $(n=1-2)$.

\begin{tabular}{cccccc}
\hline & $\mathbf{f e}$ & $\mathbf{t i}$ & $\mathbf{t a}_{\mathbf{1}}$ & $\mathbf{t a}_{\mathbf{2}}$ & $\mathbf{t a}_{\mathbf{3}}$ \\
\hline $\mathbf{p}_{\mathbf{1}}$ & $320-450$ & 190 & - & - & - \\
$\mathbf{p}_{\mathbf{2}}$ & $400-440$ & $280-380$ & - & - & - \\
$\mathbf{p}_{\mathbf{3}}$ & $410-440$ & $350-270$ & - & - & - \\
\hline & $\mathbf{t a}_{\mathbf{4}}$ & $\mathbf{t a}_{\mathbf{5}}$ & $\mathbf{L R}$ & $\mathbf{B V}$ & $\mathbf{S V}$ \\
\hline $\mathbf{p}_{\mathbf{1}}$ & - & - & - & - & - \\
$\mathbf{p}_{\mathbf{2}}$ & - & - & - & - & - \\
$\mathbf{p}_{\mathbf{3}}$ & - & - & - & - & - \\
\hline
\end{tabular}

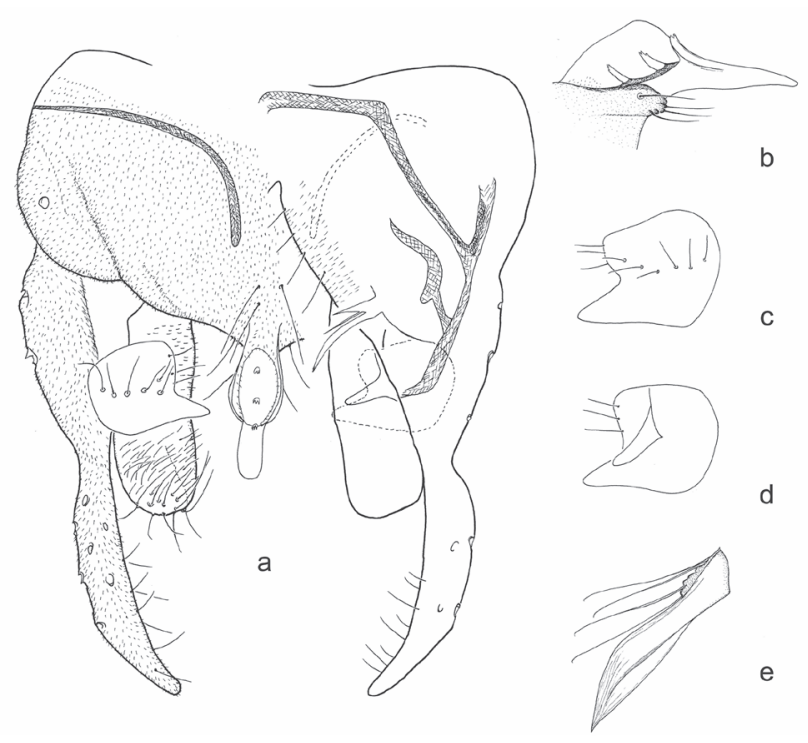

Fig. 1 Tanytarsus corumba sp. n. Adult male. a. Hypopygium, left dorsal view, right ventral view. b. Anal point, lateral view. c. Superior volsella, dorsal view. d. Superior volsella, ventral view. e. Median volsella.

Pupa and larva. Unknown.

\section{Remarks}

This species was collected in Brazilian Pantanal, with a Malaise trap (Sisbiota Project) near Eichhornia azurea (Swarts) Kunth on the river Miranda.

\section{Tanytarsus hirsutus}

Type material: Holotype male, Brazil, São Paulo, São

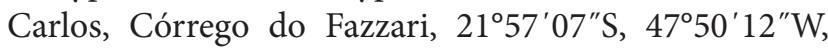
23.iii.1999, F. O. Roque. 4 Paratypes: 1 male with pupal exuviae same data as holotype except for 5.vii.2004, $\mathrm{T}$ Siqueira. 1 female with pupal exuviae and 2 males, same data as holotype except for Luiz Antônio, Estação Ecológica do Jataí, Lagoa do Diogo (associated with Eichhornia azurea), 21 $36^{\prime} 54^{\prime \prime} \mathrm{S}, 47^{\circ} 48^{\prime} 02^{\prime \prime} \mathrm{W}, 28 . v i i .2003$, S. Trivinho-Strixino.

Etymology: Derived from the Latin hirsutus, meaning hairy, and refers to the copious pilosity of the wings of this species.

Diagnostic characters: The combination of characters will separate adult males of T. hirsutus sp. n. from other Tanytarsus species: small species near $2.2 \mathrm{~mm}$; anal crests absent; anal point without spines; superior volsella elongated, median volsella present, short with short lamelae; digitus very small. The pupa is characterized by the hooked prealar tubercle; tergite II with posterior shagreen, tergite III with bands of long spines situated posteriorly, tergites IV-VI with paired point patches without shagreen, and segment VIII with 5 lateral taeniae.

\section{Description}

Adult male $(n=2)$

Dimensions: Small, length about $2.20 \mathrm{~mm}$. Wing length $1.30-1.45 \mathrm{~mm}$. 
Coloration: Head yellow-brown, flagellum and maxillary palp yellow. Thorax pale brown. Abdomen yellow; hypopygium brown. Legs yellow.

Head: AR 0.84-0.92. Antennal flagellomere lengths (in $\mu \mathrm{m}$ ): 1st-12th $450-495 \mu \mathrm{m}$ long, 13th $375-455 \mu \mathrm{m}$ long, total length 825-950 $\mu \mathrm{m}$ long. Eyes with dorsomedian extension; frontal tubercles absent; temporal 6-8; clypeus with 10-12 setae. Palpomeres 1-5 lengths: 30-33, $33-43,105-115,98-108,203-205 \mu \mathrm{m}$, total length $473-$ $498 \mu \mathrm{m}$.

Thorax: Length $0.64-0.75 \mathrm{~mm}$. Scutal tubercle absent; acrostichals 10-12, biserial, beginning near antepronotum, dorsocentrals $6-8$, prealars $2-3$, scutellars 4 . Halteres with 3-4 setae.

Wing $(\mathrm{n}=1)$ : Width $0.3 \mathrm{~mm}$; L/WR 3.05-3.41; VR 1.16. Brachiolum with 1 seta, $\mathrm{Sc}$ bare, $\mathrm{R}$ with 35 setae, $\mathrm{R}_{1}$ with 46 setae, $R_{4+5}$ with 56 setae, $M$ with 7 setae, $M_{1+2}$ with 55 setae, $\mathrm{M}_{3+4}$ with 35 setae, $\mathrm{Cu}$ with 22 setae, $\mathrm{Cu}_{1}$ with 20 setae, Postcubitus with 54 setae, An with 26 setae. Cell $\mathrm{m}$ with 32 setae most on the false vein, $\mathrm{r}_{4+5}$ with 220 setae, $\mathrm{m}_{1+2}$ with 200 setae, $\mathrm{m}_{3+4}$ with 100 setae, an $+\mathrm{cu}$ with 100 setae.

Legs: Fore leg bearing single tibial pectinate spur, 18-23 $\mu \mathrm{m}$ long. Mid leg bearing two tibial pectinate spurs, $28-30 ; 38 \mu \mathrm{m}$ long and two separated combs. Hind leg bearing two tibial pectinate spurs, $33-48 ; 25-48 \mu \mathrm{m}$ long and two separated combs. Lengths and proportions as in Table 2.

Abdomen: Length 1.48 (1) mm.

Hypopygium (Fig. 2a): Tergite IX with 6-9 apical setae, medial setae absent. Orolateral spine of laterosternite IX absent. Anal tergal bands V-type. Anal point $28 \mu \mathrm{m}$ long, pointed at tip, anal crests absent (Fig. 2b). Superior volsella elongated as figured (Fig. 2c), without field of microtrichia, median margin convex; 6 setae on dorsal surface, with 3 median setae. Digitus very short, not extending beyond median margin of superior volsella. Median volsella $13-15 \mu \mathrm{m}$ long with $13-20 \mu \mathrm{m}$ long foliate seta (Fig. 2d), not reaching apex of inferior volsella. Inferior volsella 65-78 $\mu \mathrm{m}$ long, thick. Gonocoxite length 118-120 $\mu \mathrm{m}$ long; gonostylus slender, 93-98 $\mu \mathrm{m}$ long; hypopygium ratio (HR) 1.21-1.29.

\section{Pupa $(n=1)$}

Size: Medium sized pupa, not measurable.

Coloration: Pupal exuviae pale, thorax and lateral muscle marks brown.

Cephalothorax (Fig. 3a): Frontal apotome smooth. Frontal setae thin and $37 \mu \mathrm{m}$ long. Pedicel sheath tubercle absent. Thoracic horn slender, $375 \mu \mathrm{m}$ long, with small points. Thorax smooth, $800 \mu \mathrm{m}$ long, with small points along median suture. Wing sheath with nose, prealar tubercle hook shaped. Three precorneals placed on an elevation, $\mathrm{Pc}_{1} 50 \mu \mathrm{m}$ long, $\mathrm{Pc}_{2} 30 \mu \mathrm{m}$ long, $\mathrm{Pc}_{3} 78 \mu \mathrm{m}$ long; 1 median and 2 lateral antepronotals; 2 pairs of dorsocentrals: $\mathrm{Dc}_{1} 23 \mu \mathrm{m}$ long, $\mathrm{Dc}_{2} 30 \mu \mathrm{m}$ long, $\mathrm{Dc}_{3} 25 \mu \mathrm{m}$ long, $\mathrm{Dc}_{4} 23 \mu \mathrm{m}$ long, each pair with one seta thicker.

Abdomen: Total length $1.95 \mathrm{~mm}$. Tergites I, III-VII without shagreen. T II with shagreen on posterior $1 / 4$. Tergite III with spine bands, T IV-V elongate paired point patches, T VI rounded point patches. TVIII-TIX with anterolateral shagreen (Figs. 3b-g). Sternites IVVII without shagreen. Sternites I-III with very fine shagreen and VIII with orolateral shagreen. Hook row about $1 / 4$ width of segment. Pedes Spurii A absent; Pedes Spurii $B$ present on segment II. Posterior lateral comb on segment VIII consisting of 26 subequal teeth (Fig. 3h). Anal lobe well developed, with complete fringe of 29 taeniae in single row and with two pairs of dorsal taeniae. Segment I with 1 lateral seta (not drawn); SII-SVI with 3 lateral setae; SVII with 4 lateral taeniae on posterior half; SVIII with 5 lateral taeniae.

\section{Larva. Unknown.}

\section{Remarks}

The anal point without crests and spines and the shape of anal tergite bands of Tanytarsus hirsutus sp. n. reminds T. impar Trivinho-Strixino et Strixino and T. magnus Trivinho-Strixino et Strixino. However, the small digitus and the pupal features are enough to separate T. hirsutus sp. n. from these two species. The pupa of T. hirsutus is similar to the pupal morphotype of Tanytarsus sp. 40 from Wiedenbrug and Ospina-Torres 2005 from Amazonas state indicating a probably larger distribution of this species. The Type material was collected in a lowland small stream and also in an oxbow-lake associated with Eichhornia azurea in the São Paulo state.

Table 2 Lengths (in $\mu \mathrm{m}$ ) and proportions of leg segments in Tanytarsus hirsutus sp. n., male $(n=1-2)$.

\begin{tabular}{cccccc}
\hline & $\mathbf{f e}$ & $\mathbf{t i}$ & $\mathbf{t a}_{\mathbf{1}}$ & $\mathbf{t a}_{\mathbf{2}}$ & $\mathbf{t a}_{\mathbf{3}}$ \\
\hline $\mathbf{p}_{\mathbf{1}}$ & $720-760$ & $330-360$ & $1000-1050$ & $480-520$ & $410-440$ \\
$\mathbf{p}_{\mathbf{2}}$ & $690-710$ & $530-580$ & $370-410$ & $180-190$ & $130-140$ \\
$\mathbf{p}_{\mathbf{3}}$ & $760-810$ & $680-740$ & $480-540$ & $280-320$ & $230-250$ \\
\hline & $\mathbf{t a}_{\mathbf{4}}$ & $\mathbf{t a}_{\mathbf{5}}$ & $\mathbf{L R}$ & $\mathbf{B V}$ & $\mathbf{S V}$ \\
\hline $\mathbf{p}_{\mathbf{1}}$ & $320-350$ & $140-160$ & $2.92-3.03$ & $1.48-1.52$ & $1.05-1.07$ \\
$\mathbf{p}_{\mathbf{2}}$ & 80 & $50-60$ & $0.69-0.71$ & $3.53-3.69$ & $3.15-3.29$ \\
$\mathbf{p}_{\mathbf{3}}$ & $150-160$ & 80 & $0.71-0.73$ & $2.53-2.64$ & $2.87-3.00$ \\
\hline
\end{tabular}




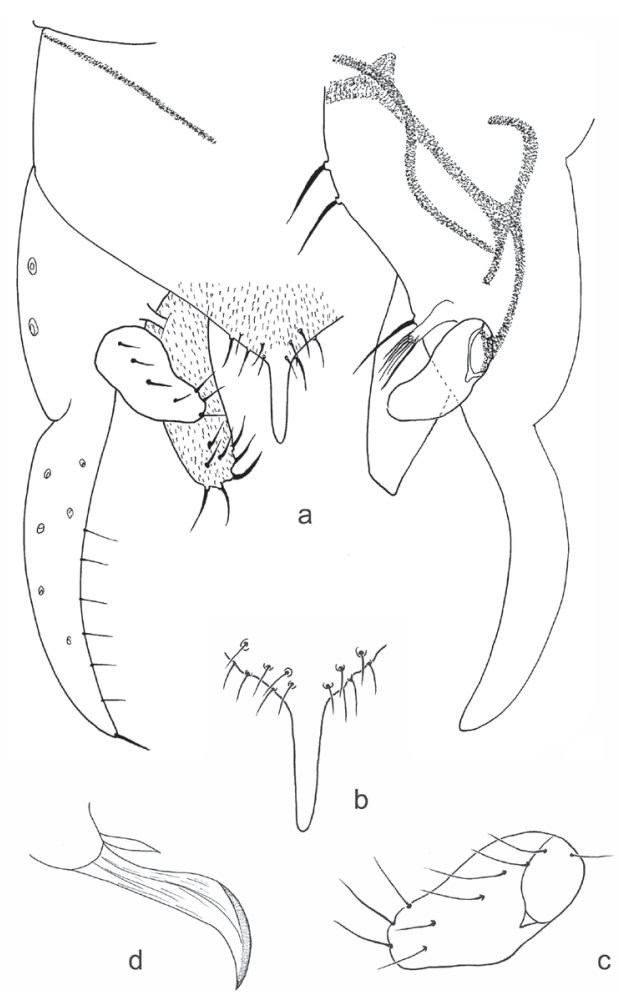

Fig. 2 Tanytarsus hirsutus sp. n. Adult male. a. Hypopygium, left dorsal view, right dorsal view, tergite IX removed. b. Anal point. c. Superior volsella. d. Median volsella.

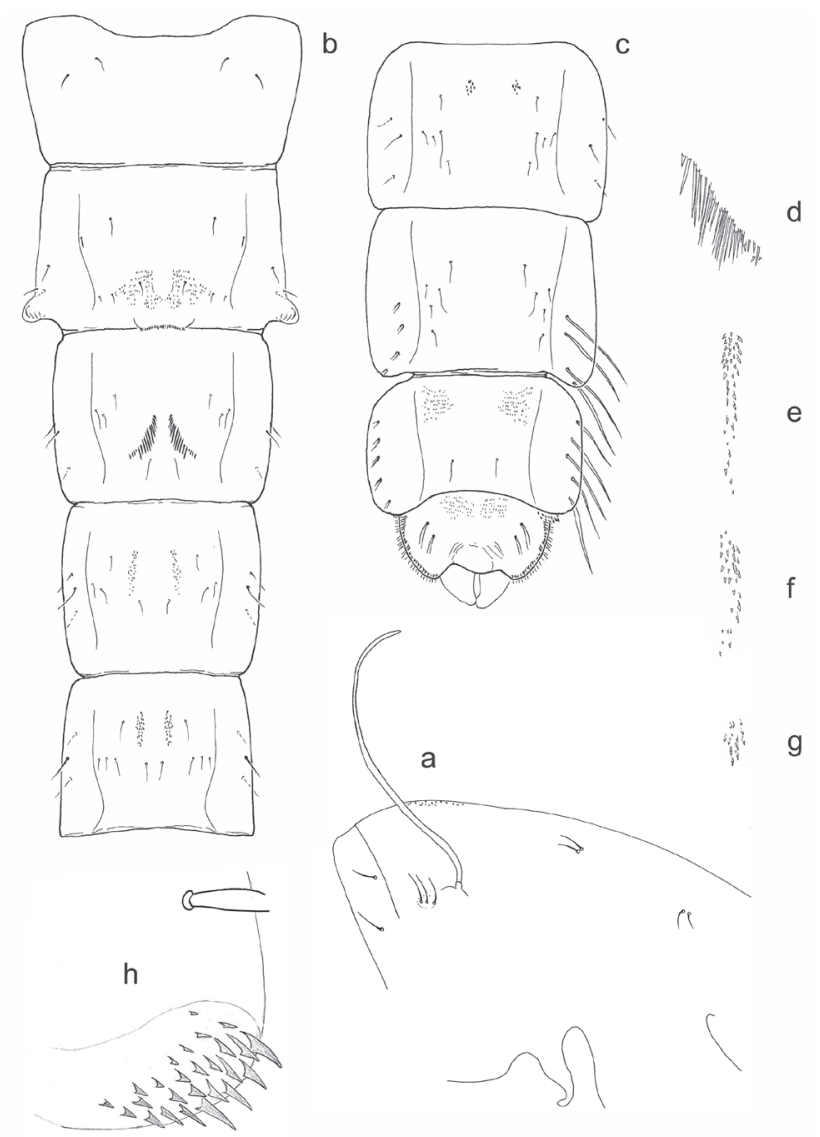

Fig. 3 Tanytarsus hirsutus sp. n. Pupa. a. Anterior part of thorax. b. Abdomen, tergites I-V. c. Abdomen, tergites VI-IX. d. Spines on tergite III. e. Point patches on tergite IV. f. Point patches on tergite V. g. Point patches on tergite VI. h. Anal comb on segment VIII.

\section{Tanytarsus jatai sp. $\mathbf{n}$.}

Type material: Holotype male, Brazil, São Paulo, Luiz Antônio, Estação Ecológica do Jataí, Lagoa do Infernão, $21^{\circ} 35^{\prime}$ S, $47^{\circ} 51^{\prime} \mathrm{W}, \mathrm{v} .1996$, K. Sonoda. 4 Paratypes: 3 males same data as holotype. 1 male, São Carlos, UFSCar, Lagoa Mayaca, $21^{\circ} 58^{\prime} 02^{\prime \prime}$ S, 47³3'01"W, 1998, S. Trivinho-Strixino.

Material examined. Mato Grosso, Nossa Sra. do Livramento, Pirizal, Baía Coqueiro, $16^{\circ} 14^{\prime}-16^{\circ} 23^{\prime} \mathrm{S}, 56^{\circ} 16^{\prime}-$ $56^{\circ} 22^{\prime} \mathrm{W}, 24 . v i .2000$, C. Butakka.

Etymology: Named after the type locality, "Estação Ecológica do Jataí" in São Paulo State. The name is treated as a noun in apposition.

Diagnostic characters: Tanytarsus jatai can be distinguished from other Tanytarsus species by the combination of the following characters: anal point thin, parallel sided, without crests and with two subapical lateral triangular projections; shape of superior volsella; digitus finger-like, extending beyond median margin of superior volsella; median volsella short.

\section{Description}

Adult male $(n=2)$

Dimensions: Small, length $2.57-2.63 \mathrm{~mm}$. Wing length $1.40-1.52 \mathrm{~mm}$.

Coloration: Head, flagellum and maxillary palp yellowish. Thorax, abdomen and legs yellow.

Head: AR 1.14-1.25. Antennal flagellomere lengths (in $\mu \mathrm{m}): 1$ st-12th $200-215 \mu \mathrm{m}$ long, 13th 245-250 $\mu \mathrm{m}$ long, total length $450-460 \mu \mathrm{m}$ long. Eyes without dorsomedian extension; frontal tubercles present, $20-28 \mu \mathrm{m}$ long, about 2.7-3.7 times as long as wide; temporal 7-9; clypeus with 10-11 setae. Palpomeres 1-5 lengths: $23-25,33-40,70-85$, 98-105, 153-160 $\mu \mathrm{m}$, total length $378-413 \mu \mathrm{m}$.

Thorax: Length $0.75-0.81 \mathrm{~mm}$. Scutal tubercle absent; acrostichals $7-8$, biserial, beginning near antepronotum, dorsocentrals 3-5, prealar 1, scutellars 2. Halteres without setae.

Wing: Width $0.40-0.42 \mathrm{~mm}$; L/WR 3.50-3.59; VR 1.27. Brachiolum with 1 seta, Sc bare, $R$ with $15-20$ setae, $\mathrm{R}_{1}$ with 13-17 setae, $\mathrm{R}_{4+5}$ with $12-16$ setae, $\mathrm{M}$ without setae, $M_{1+2}$ with 25-28 setae, $M_{3+4}$ with 7-12 setae, $\mathrm{Cu}$ without setae, $\mathrm{Cu}_{1}$ with 6-13 setae, Postcubitus without setae and An with 15-20 setae. Cell $m$ with a few setae on false vein, $r_{4+5}$ with $82-90$ setae, $m_{1+2}$ with $93-100$ setae, $\mathrm{m}_{3+4}$ with 31 (1) setae, an $+\mathrm{cu}$ without setae.

Legs: Fore leg bearing single tibial pectinate spur, 13 (1) $\mu \mathrm{m}$ long. Mid leg bearing two tibial pectinate spurs, 25 (1); 30 (1) $\mu \mathrm{m}$ long and two separated combs. Hind leg bearing two tibial pectinate spurs, 25 (1); 45 (1) $\mu \mathrm{m}$ long and two separated combs. Lengths and proportions as in Table 3.

Abdomen: Length 1.82 (1) $\mathrm{mm}$.

Hypopygium (Figs. 4a-e): Tergite IX without apical and medial setae. Orolateral spine of laterosternite IX absent. Anal tergal bands V-type. Anal point $48-53 \mu \mathrm{m}$ long, with 3 ventrolateral setae on each side, apex pointed 
to rounded, with small lateral subapical triangular projections, anal crests absent (Fig. 4b). Superior volsella with lateral field of microtrichia, median margin concave; 5-6 setae on dorsal surface, with 2 median setae. Digitus elongate, somewhat finger-like, extending beyond median margin of superior volsella (Figs. 4c-d). Median volsella short, $10-13 \mu \mathrm{m}$ long with $13 \mu \mathrm{m}$ long simple setae and $18 \mu \mathrm{m}$ long pectinate lamellae (Fig. 4e). Inferior volsella 68-70 $\mu \mathrm{m}$ long, straight. Gonocoxite length 125-133 $\mu \mathrm{m}$ long; gonostylus 83-95 $\mu \mathrm{m}$ long; hypopygium ratio (HR) 1.32-1.61.

Pupa and larva. Unknown.

\section{Remarks}

Adults of T. jatai emerged from aquatic macrophytes (Mayaca fluviatilis Aublet and Cabomba piauyhensis Gardney) maintained in laboratory. The plants were collected in oxbow lakes. T. obiriciae Trivinho-Strixino et Sonoda, T. rhabdomantis (Trivinho-Strixino et Strixino), Caladomyia riotarumensis Säwedal and C. friederi Trivinho-Strixino et Strixino were also collected in this same environment

Table 3 Lengths (in $\mu \mathrm{m}$ ) and proportions of leg segments in Tanytarsus jatai sp. n., male $(\mathrm{n}=2)$.

\begin{tabular}{cccccc}
\hline & $\mathbf{f e}$ & $\mathbf{t i}$ & $\mathbf{t a}_{\mathbf{1}}$ & $\mathbf{t a}_{\mathbf{2}}$ & $\mathbf{t a}_{\mathbf{3}}$ \\
\hline $\mathbf{p}_{\mathbf{1}}$ & $630-650$ & $290-300$ & $780-830$ & $370-420$ & $280-330$ \\
$\mathbf{p}_{\mathbf{2}}$ & $650-680$ & $490-530$ & $290-330$ & $150-160$ & $90-100$ \\
$\mathbf{p}_{\mathbf{3}}$ & $700-730$ & $640-680$ & $440-470$ & $260-300$ & $220-260$ \\
\hline & $\mathbf{t a}_{\mathbf{4}}$ & $\mathbf{t a}_{\mathbf{5}}$ & $\mathbf{L R}$ & $\mathbf{B V}$ & $\mathbf{S V}$ \\
\hline $\mathbf{p}_{\mathbf{1}}$ & $210-230$ & $100-110$ & $2.68-2.86$ & $1.62-1.75$ & $1.13-1.18$ \\
$\mathbf{p}_{\mathbf{2}}$ & $70-80$ & $50-60$ & $0.59-0.63$ & $3.86-4.05$ & $3.67-3.93$ \\
$\mathbf{p}_{\mathbf{3}}$ & $140-180$ & $80-90$ & $0.68-0.69$ & $2.26-2.50$ & $3.00-3.04$ \\
\hline
\end{tabular}

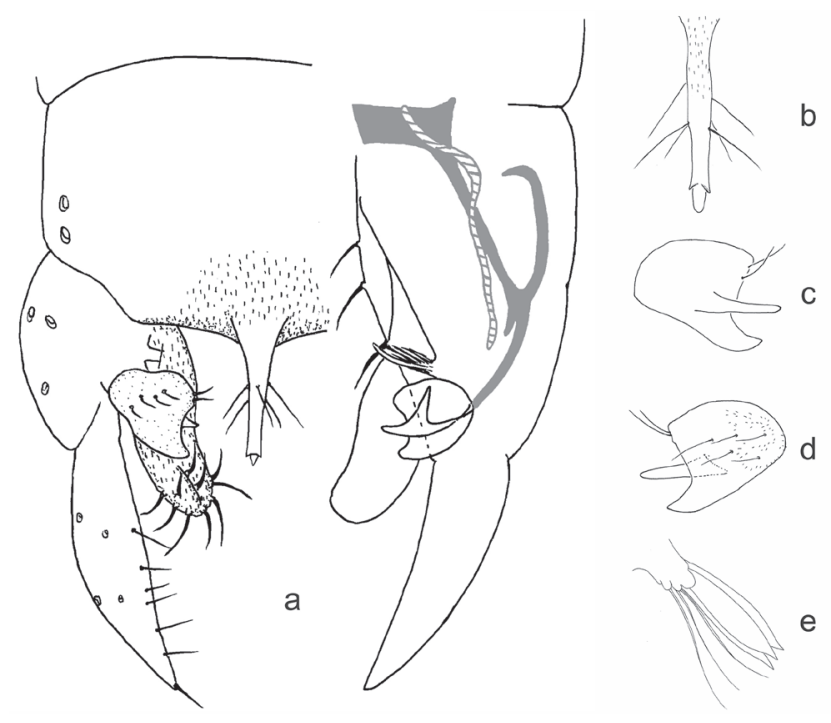

Fig. 4 Tanytarsus jatai sp. n. Adult male. a. Hypopygium, left dorsal view, right dorsal view, tergite IX removed. b. Anal point. c. Superior volsella, ventral view. d. Superior volsella dorsal view. e. Median volsella.

\section{Tanytarsus longitubuli sp. $\mathbf{n}$.}

Type material: Holotype male, Brazil, São Paulo, Luiz Antônio, Estação Ecológica do Jataí, Lagoa do Diogo, $21^{\circ} 36^{\prime} 54^{\prime \prime}$ S, 4748'02"W, 10.x.2003, S. Trivinho-Strixino. 8 Paratypes: 1 male same data as holotype, 4 males and one pharate male pupa same data as holotype except for Lagoa do Óleo $21^{\circ} 35^{\prime} 27^{\prime \prime} \mathrm{S}, 46^{\circ} 50^{\prime} 12^{\prime \prime} \mathrm{W}$. 1 male with pupal exuviae, 1 male with pupal and larval exuviae and 1 larva, São Carlos, UFSCar, Represa do Fazzari (associated with Salvinia), $21^{\circ} 59^{\prime}$ S, $47^{\circ} 54^{\prime} \mathrm{W}, 12 . v i .2007, \mathrm{H}$. R. N. Oliveira.

Etymology: Derived from the Latin longi, meaning long, and tubuli, refers to the very long anal tubules of the larvae.

Diagnostic characters: Anal tergites bands y-shaped; anal point with small crests, with one spine in between; superior volsella quadrate with a small posterior median projection, digitus finger-like, extending beyond median margin of superior volsella. Median volsella short. The pupa of T. longitubuli can be recognized by the combination of the following characters: hook row about $1 / 4$ width of segment; tergites II-VI with rounded paired point patches and additional fine shagreen; segment $\mathrm{V}$ with 3 lateral setae; VI with 2 lateral setae and 1 short posterior lateral taeniae; SVII with 4 short lateral taeniae; SVIII with 5 long lateral taeniae. The larvae differs from other Tanytarsus species by the long anal tubules.

\section{Description}

Adult male $(n=3)$

Dimensions: Small, length $1.65-1.73 \mathrm{~mm}$. Wing length $0.90-1.05 \mathrm{~mm}$.

Coloration: Head, flagellum and maxillary palp brown. Thorax dark brown. Abdomen green with conspicuous brown marks on abdominal segment IV; segments VI, VII and hypopygium brown (Fig. 5a). Legs green-yellow.

Head: AR 0.70-0.84. Antennal flagellomere lengths (in $\mu \mathrm{m}): 1$ st -12 th $370-390 \mu \mathrm{m}$ long, 13th 260-325 $\mu \mathrm{m}$ long, total length 630-715 $\mu \mathrm{m}$ long. Eyes with dorsomedian extension; frontal tubercles absent; temporal 7-8; clypeus with 8 (2) setae. Palpomeres 1-5 lengths: 20-23, 23-30, 45-53, 65-73, 105-118 $\mu \mathrm{m}$, total length 270-278 $\mu \mathrm{m}$.

Thorax: Length $0.55-0.63 \mathrm{~mm}$. Scutal tubercle absent; acrostichals 5-9, biserial, beginning near antepronotum, dorsocentrals 4-6, prealar 1, scutellars 4. Halteres with 3 (1) setae.

Wing: Width $0.28-0.30 \mathrm{~mm}$; L/WR 3.21-3.51. VR 1.28-1.30. Brachiolum with 1 (2) setae, Sc bare, R with 1 (2) seta, $R_{1}$ with 4 (2) setae, $R_{4+5}$ with 2-6 (2) setae, $M$ without setae, $M_{1+2}$ with 18-19 setae, $M_{3+4}$ with 2-4 setae, $\mathrm{Cu}$ without setae, $\mathrm{Cu}_{1}$ with 2 (1) setae, Postcubitus and An without setae. Cell $\mathrm{m}$ without setae, $\mathrm{r}_{4+5}$ with 45-56 setae, $\mathrm{m}_{1+2}$ with $48-60$ setae, $\mathrm{m}_{3+4}$ with $3-16$ setae, an $+\mathrm{cu}$ without setae.

Legs: Fore leg bearing single tibial pectinate spur, 18 (1) $\mu \mathrm{m}$ long. Mid leg bearing two tibial pectinate 
spurs, $13-25 ; 18-28 \mu \mathrm{m}$ long and two separated combs. Hind leg bearing two tibial pectinate spurs, $18-25 ; 28 \mu \mathrm{m}$ long and two separated combs. Lengths and proportions as in Table 4.

Abdomen: Length 1.10 (1) $\mathrm{mm}$.

Hypopygium (Fig. 5b): Tergite IX with 6-10 apical setae, medial setae absent. Orolateral spine of laterosternite IX absent. Anal tergal bands Y-type. Anal point 23-33 $\mu \mathrm{m}$ long, rounded at tip, with pair of well-developed anal crests $8-15 \mu \mathrm{m}$ long, extending posterior to tergite IX, with one spine between anal crests (Figs. $5 c-d$ ). Superior volsella quadrate with a small posteromedian projection, without field of microtrichia, median margin concave; 5-8 setae on dorsal surface (1-2 placed on median margin), with 2 median setae placed on tubercles. Digitus elongate, somewhat finger-like, extending beyond median margin of superior volsella (Fig. 5e). Median volsella $10 \mu \mathrm{m}$ long with 10-13 $\mu \mathrm{m}$ long simple setae and 13-18 $\mu \mathrm{m}$ long foliate setae, not reaching apex of inferior volsella (Fig. 5f). Inferior volsella 58-65 $\mu \mathrm{m}$ long, straight. Gonocoxite length 105-110 $\mu \mathrm{m}$ long; gonostylus $83 \mu \mathrm{m}$ long, somewhat elongate and slender; hypopygium ratio (HR) $1.27-1.33$.

\section{Pupa $(n=1)$}

Size: Medium sized pupa, not measurable.

Coloration: Pupal exuviae pale, thorax and lateral muscle marks brown.

Cephalothorax: Frontal apotome smooth. Frontal setae thin, $200 \mu \mathrm{m}$ long. Pedicel sheath tubercle absent. Thoracic horn slender, $350 \mu \mathrm{m}$ long, with small points. Thorax smooth, $500 \mu \mathrm{m}$ long, with small points along median suture. Wing sheath with nose, prealar tubercle absent. Three precorneals in a triangular pattern, not placed on an elevation, $\mathrm{Pc}_{1} 53 \mu \mathrm{m}$ long, $\mathrm{Pc}_{2} 43 \mu \mathrm{m}$ long, $\mathrm{Pc}_{3} 43 \mu \mathrm{m}$ long; 1 median and 1 lateral antepronotals; 2 pairs of dorsocentrals: $\mathrm{Dc}_{1} 35 \mu \mathrm{m}$ long, $\mathrm{Dc}_{2} 35 \mu \mathrm{m}$ long, $\mathrm{Dc}_{3}$ and $\mathrm{Dc}_{4}$ not measurable, each pair with one seta thicker.

Abdomen (Figs. 6a-b): Total length $1.37 \mathrm{~mm}$. Tergites I without shagreen. T II-IV with homogeneous shagreen. T V-VI with sparse shagreen. T VII-TIX with orolateral shagreen. Sternites, conjunctives and pleura unarmed. Tergites II-VI with paired point patches. Hook row

Table 4 Lengths (in $\mu \mathrm{m}$ ) and proportions of leg segments in Tanytarsus longitubuli sp. $\mathrm{n}$., male $(\mathrm{n}=2-3)$.

\begin{tabular}{cccccc}
\hline & $\mathbf{f e}$ & $\mathbf{t i}$ & $\mathbf{t a}_{\mathbf{1}}$ & $\mathbf{t a}_{\mathbf{2}}$ & $\mathbf{t a}_{\mathbf{3}}$ \\
\hline $\mathbf{p}_{\mathbf{1}}$ & $420-450$ & $190-200$ & $460-500$ & $260-290$ & $210-240$ \\
$\mathbf{p}_{\mathbf{2}}$ & $430-480$ & $330-350$ & $200-210$ & 90 & 60 \\
$\mathbf{p}_{\mathbf{3}}$ & $510-530$ & $410-450$ & $290-330$ & $160-180$ & 160 \\
\hline & $\mathbf{t a}_{\mathbf{4}}$ & $\mathbf{t a}_{\mathbf{5}}$ & $\mathbf{L R}$ & $\mathbf{B V}$ & $\mathbf{S V}$ \\
\hline $\mathbf{p}_{\mathbf{1}}$ & $150-160$ & $80-90$ & $2.35-2.42$ & $1.50-1.51$ & $1.30-1.32$ \\
$\mathbf{p}_{\mathbf{2}}$ & 50 & $40-50$ & $0.61-0.62$ & $3.92-4.08$ & $3.67-3.91$ \\
$\mathbf{p}_{\mathbf{3}}$ & $90-100$ & $60-70$ & $0.70-0.73$ & $2.47-2.67$ & $2.97-3.17$ \\
\hline
\end{tabular}

about $1 / 4$ width of segment. Pedes Spurii A absent; Pedes Spurii B present on segment II. Posterior lateral comb of segment VIII consisting of 3 stronger marginal teeth and 3 smaller ones (Fig. 6c). Anal lobe well developed, with complete fringe of 15 taeniae in single row and with two pairs of dorsal taeniae. Lateral setae on segment I not observed; SII-SV with 3 lateral setae; SVI with 2 lateral setae and 1 posterior lateral taenia; SVII with 4 lateral taeniae; SVIII with 5 lateral taeniae.

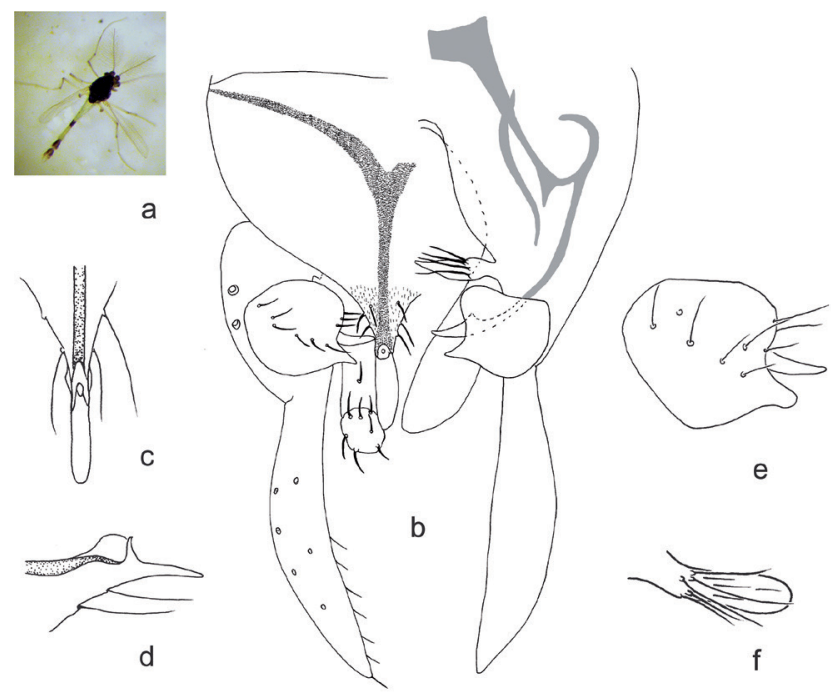

Fig. 5 Tanytarsus longitubuli sp. n. Adult male. a. Overview of adult male. b. Hypopygium, left dorsal view, right dorsal view, tergite IX removed. c. Anal point, dorsal view. d. Anal point, lateral view. e. Superior volsella, f. Median volsella.

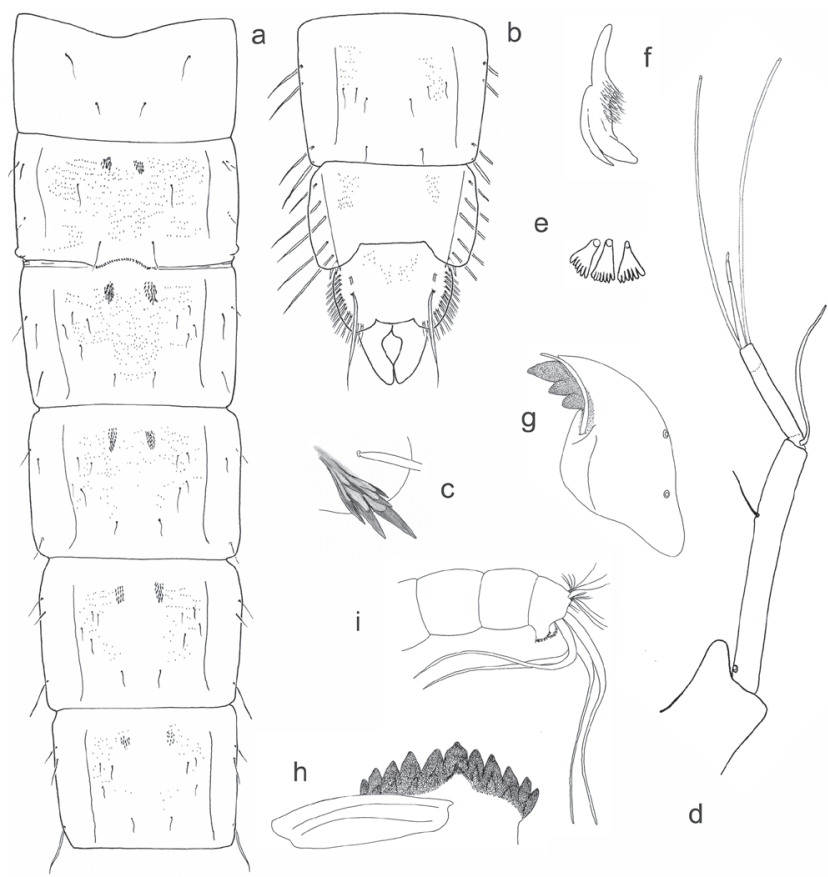

Fig. 6 Tanytarsus longitubuli sp. n. Immature stages. a-c Pupa. d-i Larva. a. Tergites I-VI. b. Tergites VII-IX. c. Detail of posterior lateral comb of segment VIII. d. Antenna. e. Pecten epipharyngis. f. Premandible. g. Mandible. h. Mentum. i. Posterior abdominal segments. 
Larva $(n=1)$

Size: Length $2.8 \mathrm{~mm}$ long, colour orange-red.

Coloration: Body pale red; head yellow; antenna brow; mentum with median tooth dark brown; mandible with dorsal tooth pale, apical tooth and 2 inner teeth brown.

Head: Length $213 \mu \mathrm{m}$, width $233 \mathrm{~mm}$; cephalic index 1.09 .

Antenna (Fig. 6d): Length $225 \mu \mathrm{m}$ long, mounted on a prominent pedestal, without distal spur; AR 1.25. Basal segment with proximal ring organ and with developed seta placed at base of segment; antennal blade seated distally on basal segment, $70 \mu \mathrm{m}$ long. Lauterborn organs short, pedicels including LO, $169 \mu \mathrm{m}$ long.

Labrum: Pecten epipharyngis consisting of 3 distally serrated scales (Fig. 6e). Premandible with 3 teeth, brush well developed (Fig. 6f).

Mandible (Fig. 6g): Length $106 \mu \mathrm{m}$ long. Seta subdentalis long and curved, extending a little beyond mandible apex.

Mentum (Fig. 6h): Width $69 \mu \mathrm{m}$, with 5 pairs of lateral teeth decreasing in size laterally. Ventromental plates width $69 \mu \mathrm{m}$ long, slightly separated medially and weakly striated.

Body: Claws of posterior parapods simple. Anal tubules large and elongate, near 10 times longer than posterior parapods (Fig. 6i). Procercus with dark setae.

\section{Remarks}

The Type material was collected in lakes associated with roots of Salvinia auriculata (Aublet) in São Paulo state. The larvae construct long cocoons that are attached to the roots of Salvinia. It is likely the larvae do not abandon these cocoons until emergence. The long anal tubules are the most distinctive features of this species.

\section{Tanytarsus pseudocurvicristatus sp. $\mathbf{n}$.}

Type material: Holotype male with pupal and larval exuviae, Brazil, São Paulo, São Carlos, Córrego do Fazzari, $21^{\circ} 57^{\prime} 07^{\prime \prime}$ S, 4750'12"W, viii.2001, F. O. Roque. 1 Paratype: 1 male same data as holotype except for 17.viii.1999.

Etymology: The species is named T. pseudocurvicristatus because of the close resemblance to the adult of T. curvicristatus.

Diagnostic characters: Anal tergite bands V-shaped with medial setae between bands. Anal point with one group of spines posteriorly directed, one bar placed posterior and anteriorly directed divided at apex, anal crests present anterior on anal point. The pupa can be recognized by the tergites II-VI with paired point patches present. TII with two shagreen patches on posterior $1 / 4$. TIII-VI with sparse shagreen. Segment VIII with 4 pair of lateral taeniae. The very long antenna, with long segment 1 and longer segment 2 and also the long Lauterborn pedicels, all non-annulated are typical for the larva of this species.

\section{Description}

Adult male $(n=2)$

Dimensions: Small, length 2.37-2.47 mm. Wing length $1.35-1.40 \mathrm{~mm}$.

Coloration: Head, flagellum and maxillary palp yellow. Thorax, abdomen and legs yellow.

Head: AR 0.85-0.88. Antennal flagellomere lengths (in $\mu \mathrm{m})$ : 1st-12th 475-485 $\mu \mathrm{m}$ long, 13th 405-425 $\mu \mathrm{m}$ long, total length 880-910 $\mu \mathrm{m}$ long. Eyes with dorsomedian extension; frontal tubercles absent; temporal 9 (1); clypeus with 7 (1) setae. Palpomeres 1-5 lengths: 25-30, 33 38 , 90-93, 90-95, 165-180 $\mu \mathrm{m}$, total length 413-425 $\mu \mathrm{m}$.

Thorax: Length $0.67-0.77 \mathrm{~mm}$. Scutal tubercle absent; acrostichals 10-11, biserial, beginning near antepronotum, dorsocentrals 5-7, prealar 1, scutellars 4 . Setae on halteres absent.

Wing: Width 0.37-0.42 mm; L/WR 3.29-3.60. VR 1.22. Brachiolum with 2 setae, Sc bare, $\mathrm{R}$ with $20-22$ setae, $R_{1}$ with $18-23$ setae, $R_{4+5}$ with $42-44$ setae, $M$ without setae, $M_{1+2}$ with 41-56 setae, $M_{3+4}$ with 26-31 setae, $\mathrm{Cu}$ with 9 setae, $\mathrm{Cu}_{1}$ with 15-21 setae, Postcubitus with 19 setae, An with 15-22 setae. Cell $m$ with 6-8 setae on false vein, $\mathrm{r}_{4+5}$ with $188-195$ setae, $\mathrm{m}_{1+2}$ with $120-144$ setae, $m_{3+4}$ with $68-71$ setae, an + cu with $54-72$ setae.

Legs: Fore leg bearing single tibial pectinate spur, 28 (1) $\mu \mathrm{m}$ long. Mid leg bearing two tibial pectinate spurs, 25-30; 38-43 $\mu \mathrm{m}$ long and two separated combs. Hind leg bearing two tibial pectinate spurs, 30-48; $50 \mu \mathrm{m}$ long and two separated combs. Lengths and proportions as in Table 5 .

Abdomen: Length 1.70 (1) mm.

Hypopygium (Figs. 7a-e): Tergite IX with 6 apical setae on each side and 6-7 medial setae. Orolateral spine of laterosternite IX absent. Anal tergal bands V-type. Anal point 40-43 $\mu \mathrm{m}$ long, pointed at tip, with pair of well-developed anal crests 23-25 $\mu \mathrm{m}$ long, extending posterior to tergite IX, with one group of spines posteriorly directed, one bar placed posterior and anteriorly directed divided at apex (Figs. 7b-c). Superior volsella without field of microtrichia, median margin concave; 4 setae on dorsal surface, 3 median setae, one of them located on tubercle (Figs. 7d-e). Digitus short, somewhat finger-like, not ex-

Table 5 Lengths (in $\mu \mathrm{m}$ ) and proportions of leg segments in Tanytarsus pseudocurvicristatus sp. $n$., male $(n=1-2)$.

\begin{tabular}{cccccc}
\hline & $\mathbf{f e}$ & $\mathbf{t i}$ & $\mathbf{t a}_{\mathbf{1}}$ & $\mathbf{t a}_{\mathbf{2}}$ & $\mathbf{t a}_{\mathbf{3}}$ \\
\hline $\mathbf{p}_{\mathbf{1}}$ & $770-800$ & $360-370$ & 980 & 450 & 350 \\
$\mathbf{p}_{\mathbf{2}}$ & 730 & 550 & 320 & 150 & 100 \\
$\mathbf{p}_{\mathbf{3}}$ & $790-820$ & $670-680$ & $480-490$ & $260-270$ & $220-230$ \\
\hline & $\mathbf{t a}_{\mathbf{4}}$ & $\mathbf{t a}_{\mathbf{5}}$ & $\mathbf{L R}$ & $\mathbf{B V}$ & $\mathbf{S V}$ \\
\hline $\mathbf{p}_{\mathbf{1}}$ & 250 & 130 & 2.64 & 1.82 & 1.19 \\
$\mathbf{p}_{\mathbf{2}}$ & 70 & 50 & 0.58 & 4.32 & 4.00 \\
$\mathbf{p}_{\mathbf{3}}$ & $120-130$ & 80 & $0.70-0.73$ & $2.74-2.91$ & $2.97-3.12$ \\
\hline
\end{tabular}


tending beyond median margin of superior volsella. Median volsella $23 \mu \mathrm{m}$ long with $10-13 \mu \mathrm{m}$ long simple setae and 13-18 $\mu \mathrm{m}$ long subulate lamellae, not reaching apex of inferior volsella (Fig. 7f). Inferior volsella 55-65 $\mu \mathrm{m}$ long, straight. Gonocoxite length 135-155 $\mu \mathrm{m}$ long; gonostylus slender, $103 \mu \mathrm{m}$ long; hypopygium ratio (HR) 1.32-1.51.

Pupa $(n=1)$

Size: Medium sized pupa, not measurable.

Coloration: Pupal exuviae pale, thorax and lateral muscle marks brown.

Cephalothorax (Fig. 8a): Frontal apotome smooth. Frontal setae thin, not measurable. Pedicel sheath tubercle absent. Thoracic horn slender, $495 \mu \mathrm{m}$ long, with small points. Thorax smooth, $680 \mu \mathrm{m}$ long, with small points along median suture. Wing sheath with nose, prealar tubercle absent. Three precorneals in a triangular pattern, not placed on an elevation, $\mathrm{Pc}_{1} 43 \mu \mathrm{m}$ long, $\mathrm{Pc}_{2}$ $25 \mu \mathrm{m}$ long, $\mathrm{Pc}_{3} 53 \mu \mathrm{m}$ long; 1 median and 1 lateral antepronotals; 2 pairs of dorsocentrals: $\mathrm{Dc}_{1} 18 \mu \mathrm{m}$ long, $\mathrm{Dc}_{2}$ $28 \mu \mathrm{m}$ long, $\mathrm{Dc}_{3} 50 \mu \mathrm{m}$ long, $\mathrm{Dc}_{4} 70 \mu \mathrm{m}$ long, each pair with one seta thicker.

Abdomen (Figs. 8b-c): Length not measurable. Tergites I, IV-VII without shagreen. TII with two shagreen patches on posterior $1 / 4$. TIII-VI with sparse shagreen, not drawn. Tergite II-VI with paired point patches (Figs. 8d-h). TVII-TIX with anterolateral shagreen, not drawn. Sternites, conjunctives and pleura unarmed. Hook row about $1 / 3$ width of segment. Pedes Spurii A absent; Pedes Spurii B present on segment II. Posterior lateral comb consisting of 2 stronger marginal teeth and 4 smaller one (Fig. 8i). Anal lobe well developed, with complete fringe of 21 taeniae in single row and with two pairs of dorsal taeniae. Segment I without lateral setae; SII-SI with 3 lateral setae; SVI-VI with 3 lateral taeniate setae; SVII-VIII with 4 lateral taeniae.

\section{Larva $(n=1)$}

Size: Length $2.8 \mathrm{~mm}$ long, colour orange-red. Dorsal tooth pale, apical tooth and 2 inner teeth brown. Mentum with median tooth pale.

Head: Length $344 \mu \mathrm{m}$, width $281 \mathrm{~mm}$; cephalic index 0.82 .

Antenna (Fig. 8j): Length $587 \mu \mathrm{m}$ long, mounted on a prominent pedestal, without distal spur; AR 0.65. Basal segment with proximal ring organ and with developed seta placed at base of segment; antennal blade seated distally on basal segment, $57 \mu \mathrm{m}$ long.

Labrum: Pecten epipharyngis consisting of 3 distally serrated scales. Premandible with 3 teeth, brush well developed.

Mandible (Fig. 8k): Length $92 \mu \mathrm{m}$ long. Seta subdentalis long and curved, extending a little beyond mandible apex.

Mentum (Fig. 81): Width $78 \mu \mathrm{m}$, with 5 pairs of lateral teeth decreasing in size laterally. Ventromental plates

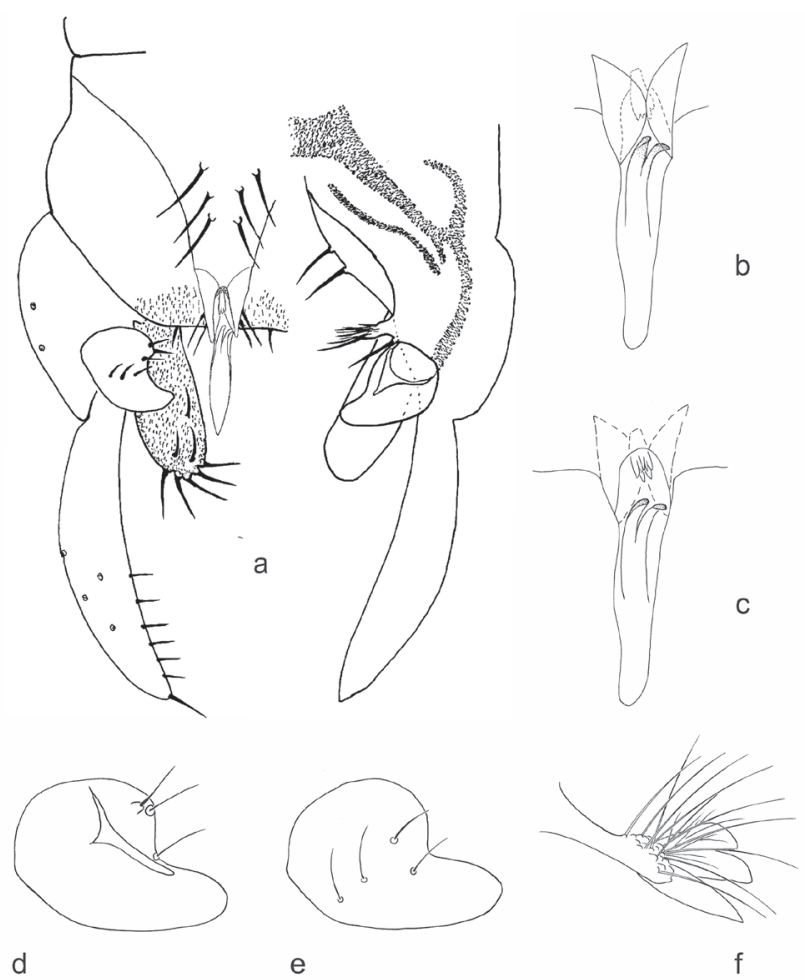

Fig. 7 Tanytarsus pseudocurvicristatus sp. n. Adult male. a. Hypopygium, left dorsal view, right dorsal view, tergite IX removed. b-c. Anal point, b. dorsal view, c. dorsal view without anal crests. d. Superior volsella ventral view. e. Superior volsella, dorsal view. f. Median volsella.
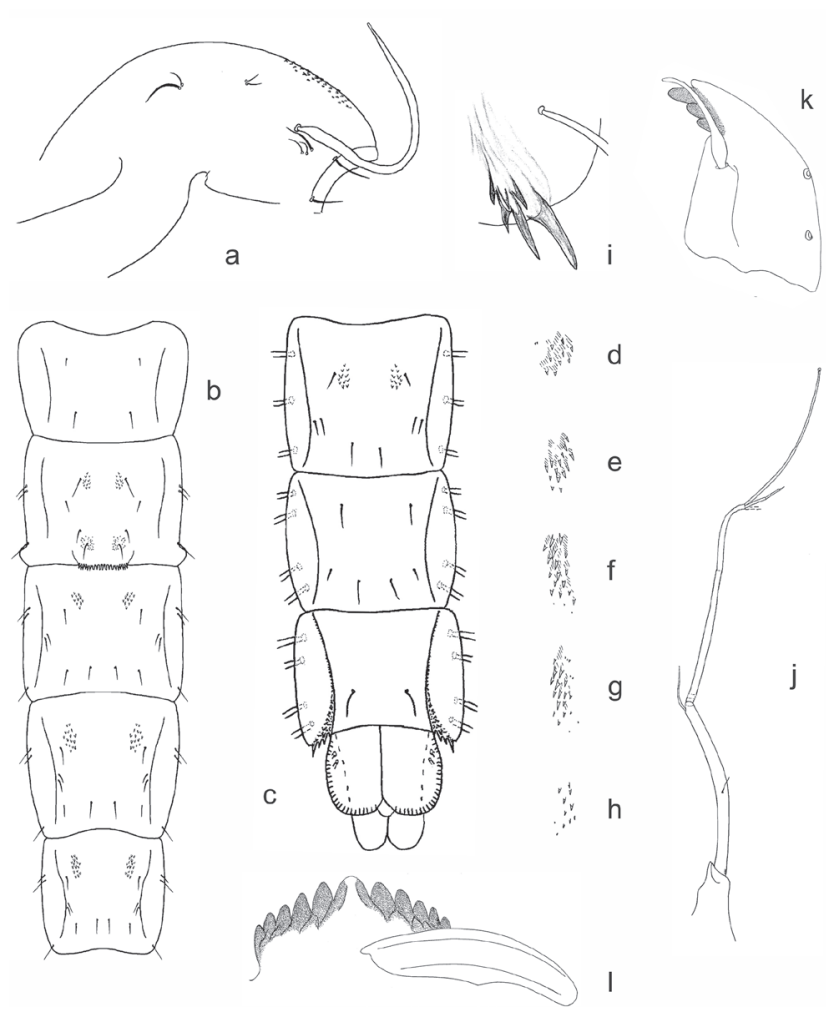

Fig. 8 Tanytarsus pseudocurvicristatus sp. n. Immature stages. a-i. Pupa. j-I. Larva. a. Anterior part of thorax. b. Abdomen, tergites I-V. c. Abdomen, tergites VI-IX. d. Spines on tergite II. e. Point patches on tergite III. f. Point patches on tergite IV. g. Point patches on tergite V. h. Point patches on tergite VI. i. Anal comb on segment VIII. j. Antenna. k. Mandible. I. Mentum. 
width $86 \mu \mathrm{m}$ long, slightly separated medially and weakly striated.

Body: Claws of posterior parapods simple. Anal tubules large and elongate. Procercus with dark setae.

\section{Remarks}

Tanytarsus pseudocurvicristatus is very similar to T. curvicristatus Contreras-Lichtenberg, but can be separated from the former by the medial setae between anal tergal bands - T. curvicristatus has the medial setae in two groups at the end of anal tergite bands (Contreras-Lichtenberg 1988). Immature stages of T. curvicristatus are not known, whereas the immature stages of T. pseudocurvicristatus were sampled in the Córrego do Fazzari, a small slow flowing low land stream.

New occurrences of known species of Tanytarsus in Brazil (MS, MT).

Tanytarsus giovannii Sanseverino et Trivinho-Strixino. MS, Corumbá, BEP, Mata ciliar, Rio Miranda, $19^{\circ} 34^{\prime} 30.06^{\prime \prime} \mathrm{S}, \quad 57^{\circ} 00^{\prime} 52.4^{\prime \prime} \mathrm{W}$, Malaise 3, 02 x.-02. xii.2011, C. J. E. Lamas, S. S. Nihei et al. (SISBIOTAProject).

Tanytarsus ligulatus Reiss. MT, Ribeirão Cascalheira, Rio Suiamissu, Fazenda Campina Verde; 1248'59"S, 52 06'92"W, 20.x.2007, leg. L.C. Pinho et al.; MT, Nossa Sra. do Livramento, Pirizal, Baía Coqueiro, $16^{\circ} 14^{\prime}-$ $16^{\circ} 23^{\prime} \mathrm{S}, 56^{\circ} 16^{\prime}-56^{\circ} 22^{\prime} \mathrm{W}, 30 . v i i .2000$, C. Butakka.

Tanytarsus obiriciae Trivinho-Strixino et Sonoda. MS, Corumbá, BEP, Mata ciliar, Rio Miranda, $19^{\circ} 34^{\prime} 30.06^{\prime \prime} \mathrm{S}, 57^{\circ} 00^{\prime} 52.4^{\prime \prime} \mathrm{W}$, Malaise 3, 02 xi.-02. xii.2011, C. J. E. Lamas, S. S. Nihei et al. (SISBIOTAProject). MT, Nossa Sra. do Livramento, Pirizal, Baía Coqueiro, $16^{\circ} 14^{\prime}-16^{\circ} 23^{\prime} \mathrm{S}, 56^{\circ} 16^{\prime}-56^{\circ} 22^{\prime} \mathrm{W}, 30 . v i i .2000$, C. Butakka.

\section{Acknowledgements}

We would like to thank Fabio de Oliveira Roque and Kathia Sonoda for providing us with important material. We are indebted to Angela Manzolillo Sanseverino, who helped us with the interpretation of several hypopygial structures and made several comments and suggestions. Thanks also to the Conselho Nacional de De- senvolvimento Científico e Tecnológico (CNPq) (Proc. No. 563256/2010-9) and Fundação de Amparo a Pesquisa do Estado de São Paulo (FAPESP) (Proc. No. 2010/523140 ) for the support to the SISBIOTA Project.

\section{REFERENCES}

Contreras-Lichtenberg R (1988) Tanytarsus curvicristatus spec. nov. eine neue Chironomidenart aus Columbien. Spixiana Suppl 14: 101-114.

Cranston PS (2007) A new species for a Bromeliad Phytotelm-Dwelling Tanytarsus (Diptera: Chironomidae). Ann Entomol Soc Am 100: 617-622.

Ekrem T, Reiss F (1999) Two new Tanytarsus species (Diptera: Chironomidae) from Brazil, with reduced median volsella. Aquat Insect 21: 205-213.

Gilka W, Zakrzewska M (2013) A contribution to the systematics of Neotropical Tanytarsus van der Wulp: first descriptions from Ecuador (Diptera: Chironomidae: Tanytarsini). Zootaxa 3619: 453-459.

Manzolillo-Sanseverino MA (2006) A review of the genus Tanytarsus van der Wulp1874 (Insecta, Diptera, Chironomidae) from the Neotropical Region. PhD Thesis, Ludwig Maximilian University, Munich. http://edoc.ub.uni-muenchen.de/4975/. Accessed 17 October 2014.

Sæther OA (1980) Glossary of chironomid morphology terminology (Diptera: Chironomidae). Entomol Scand Suppl 14: 1-51.

Sanseverino AM, Fittkau EJ (2006) Four new species of Tanytarsus van der Wulp, 1874 (Diptera: Chironomidae) from South America. Zootaxa 1162: 1-18.

Sanseverino AM, Trivinho-Strixino S (2010) New Species of Tanytarsus van der Wulp (Diptera: Chironomidae) from São Paulo State, Brazil. Neotrop Entomol 39: 67-82.

Sanseverino AM, Trivinho-Strixino S, Nessimian JL (2010) Taxonomic status of Nimbocera Reiss, 1972, a junior synonym of Tanytarsus van der Wulp, 1874 (Diptera: Chironomidae). Zootaxa 2359: 43-57.

Trivinho-Strixino S, Sonoda K (2006) A new Tanytarsus species (Insecta, Diptera, Chironomidae) from São Paulo State, Brazil. Biota Neotrop 6: 1-9.

Trivinho-Strixino S, Strixino G (2007) A new Neotropical species of Tanytarsus van der Wulp, 1874 (Diptera: Chironomidae), with an unusual anal process. Zootaxa 1654: 61-67.

Vinogradova EM, Riss HW, Spies M (2009) New species of Tanytarsus van der Wulp, 1874 (Diptera: Chironomidae) from Central America. Aquat Insect 31: 11-17.

Wiedenbrug S, Ospina-Torres R (2005) A key to pupal exuviae of Neotropical Tanytarsini (Diptera: Chironomidae). Amazoniana $18: 317-371$. 